\title{
Erythropoietin Receptor
}

National Cancer Institute

\section{Source}

National Cancer Institute. Erythropoietin Receptor. NCI Thesaurus. Code C17295.

Erythropoietin receptor ( $508 \mathrm{aa}, \sim 55 \mathrm{kDa}$ ) is encoded by the human EPOR gene. This

protein is involved in signal transduction and erythroblast proliferation and differentiation. 